\title{
Anti-inflammatory effects of Lactobacillus casei BL23 producing or not a manganese-dependant catalase on DSS-induced colitis in mice Tatiana Rochat ${ }^{1}$, Luis Bermúdez-Humarán ${ }^{1}$, Jean-Jacques Gratadoux¹, Christel Fourage ${ }^{1}$, Christine Hoebler ${ }^{2}$, Gérard Corthier ${ }^{1}$ and Philippe Langella*1
}

\begin{abstract}
Address: ${ }^{1}$ Unité d'Ecologie et Physiologie du Système Digestif, Centre de Recherche INRA, Domaine de Vilvert, 78352 Jouy-en-Josas cedex, France and 2Physiologie Intestinale, Croissance et Nutrition Humaine, UMR INRA/Université de Nantes, Rue de la Géraudière - BP 71627, 44316 Nantes cedex 3, France

Email: Tatiana Rochat - tatiana.rochat@jouy.inra.fr; Luis Bermúdez-Humarán - luis.bermudez@jouy.inra.fr; Jean-Jacques Gratadoux - jeanjacques.gratadoux@jouy.inra.fr; Christel Fourage - christel.fourage@yahoo.fr; Christine Hoebler - christine.hoebler@jouy.inra.fr;

Gérard Corthier - gerard.corthier@jouy.inra.fr; Philippe Langella* - philippe.langella@jouy.inra.fr

* Corresponding author
\end{abstract}

Published: 20 July 2007

Received: 8 March 2007

Microbial Cell Factories 2007, 6:22 doi:10.1 186/1475-2859-6-22

Accepted: 20 July 2007

This article is available from: http://www.microbialcellfactories.com/content/6/1/22

(c) 2007 Rochat et al; licensee BioMed Central Ltd.

This is an Open Access article distributed under the terms of the Creative Commons Attribution License (http://creativecommons.org/licenses/by/2.0), which permits unrestricted use, distribution, and reproduction in any medium, provided the original work is properly cited.

\begin{abstract}
Background: Human immune cells generate large amounts of reactive oxygen species (ROS) throughout the respiratory burst that occurs during inflammation. In inflammatory bowel diseases, a sustained and abnormal activation of the immune system results in oxidative stress in the digestive tract and in a loss of intestinal homeostasis. We previously showed that the heterologous production of the Lactobacillus plantarum ATCCI443I manganese-dependant catalase (MnKat) in $L b$. casei BL23 successfully enhances its survival when exposed to oxidative stress. In this study, we evaluated the preventive effects of this antioxidative $L b$. casei strain in a murine model of dextran sodium sulfate (DSS)-induced moderate colitis.
\end{abstract}

Results: Either Lb. casei BL23 MnKat- or MnKat ${ }^{+}$was administered daily to mice treated with DSS for 10 days. In contrast to control mice treated with PBS for which DSS induced bleeding diarrhea and mucosal lesions, mice treated with both $L b$. casei strains presented a significant $(p<0.05)$ reduction of caecal and colonic inflammatory scores.

Conclusion: No contribution of MnKat to the protective effect from epithelial damage has been observed in the tested conditions. In contrast, these results confirm the high interest of $L b$. casei as an anti-inflammatory probiotic strain.

\section{Background}

Inflammatory bowel diseases (IBD), including Crohn's disease and ulcerative colitis, are characterised by an abnormal activation of the gut-associated immune system resulting in a chronic inflammation of the digestive tract (DT). IBD patients show flares of remission and relapses with symptoms of bloody diarrhea, abdominal pain and rectal bleeding. Although the etiology of IBD remains unclear, it is generally considered that a combination of several factors including genetic predisposition, immune disorders and environmental factors could be involved. The role of commensal and pathogenic bacteria in the 
induction of these diseases is particularly well documented [1-7].

Recent studies linked intestinal oxidative stress to the observed epithelial damage. In small quantities, reactive oxygen species (ROS) are involved in certain signalization or regulation pathways. During normal inflammation, ROS toxicity leads to the elimination of infectious agents: ROS are generated inside the DT during oxidative burst by activated phagocyte cells which possess ROS-producing enzymes, such as NADPH oxidase [8], NO synthase [9] and myeloperoxidase [10] and they infiltrate the lamina propria. However, in the case of IBD, excessive amounts of ROS accumulate and lead to oxidative epithelial damage. Several studies have shown a correlation between the increase in ROS production and disease activity in inflamed biopsies of IBD patients [11-14]. The measured effects on antioxidative systems diverge between studies: antioxidative enzyme activity was either increased $[15,16]$ or decreased [12] in IBD biopsies, depending on the nature of the enzyme and the state of disease activity. Moreover, several studies provide direct evidence of in vivo oxidative injury in inflamed epithelial cells of IBD patients $[12,17,18]$. Recently, several antioxidative strategies have been evaluated using animal colitis models and appear to be efficient in the reduction of inflammatory damage [19-23]. These antioxidative strategies could be based on the activity of two enzymes: superoxide dismutase (SOD) which reduced superoxides and catalases which catabolized in $\mathrm{H}_{2} \mathrm{O}+\mathrm{O}_{2}$ the hydrogen peroxide resulting from the reduction of superoxides. Here, we proposed to evaluate the efficiency of in situ delivery of one catalase by the lactic acid bacterium (LAB) Lactobacillus casei. In parallel to their traditional use for the production of fermented products, LAB are also studied for their probiotic properties. Some strains could improve IBD patients' health, as it observed, for example, with the administration of the VSL\#3 probiotic cocktail which delayed the relapse into pouchitis after surgical resection $[24,25]$. Natural anti-inflammatory effects were recently shown for $L b$. salivarius [26], Bifidobacterium and $L b$. plantarum $[27,28]$ and $\mathrm{Lb}$. casei Shirota $[29,30]$ using experimental colitis models. New recombinant strategies are also in progress to engineer LAB strains for in situ delivery of heterologous therapeutic proteins. This strategy has been first applied to IBD, where the intragastric administration of a genetically engineered $L$. lactis strain producing an anti-inflammatory cytokine, the interleukin-10 (IL$10)$, caused a significant reduction in colitis in mice treated with DSS [31].

We previously showed that the improvement of the antioxidative capacities of Lactococcus lactis and Lb. casei by the introduction of a catalase gene led to an increase of bacterial survival in the presence of hydrogen peroxide and under aerated conditions. We evaluated the in vitro catalase activity of $L b$. casei BL23 producing the manganesedependant catalase (hereafter called MnKat) from $L b$. plantarum ATCC14431 [32] at $16 \mu \mathrm{mol}$ of $\mathrm{H}_{2} \mathrm{O}_{2} / \mathrm{min} / \mathrm{mg}$ of protein $[33,34]$. In this study, the preventive effects of two isogenic $L b$. casei strains producing or not MnKat on the development of the inflammation were analyzed using a DSS-induced intestinal colitis model in BALB/C mice. We tested in vivo whether the MnKat-producing $L b$. casei strain could reduce epithelial damage of the digestive tract.

\section{Results}

\section{Characterization of DSS-induced colitis}

We first analyzed the effect of 1\% DSS administration to mice for 10 days on clinical symptoms and inflammatory scores using the experimental design described in Figure 1. After 10 days of DSS administration, no significant differences in decrease of body weight, food and water intake, were observed between group B (1\% DSS) and group A (0\% DSS) (data not shown). Total stool score (based on consistency of stool and bleeding) was significantly increased in group $\mathrm{B}$ when compared to the untreated group A (10 versus $\sim 0$; data not shown), with bleeding stools for all mice of group B during the experiment. The macroscopic score (mucosal thickening, hyperaemia, ulcerations) was also significantly increased in DSS-treated group (Figure 2A). The percentage of intact mucosa, taking into account shortening of the crypts and inflammatory infiltrates, decreased significantly showing histological damages (Figure 2B). Ours results showed that i) inflammatory symptoms induced by our experimental protocol are significantly different between treated and untreated groups and ii) intestinal inflammation corresponds to moderate colitis. In parallel, a more drastic treatment (5\% DSS for 10 days; group E) was tested as a severe colitis control group. In this case, we observed i) a decrease $(15 \%)$ of body weight compared to untreated mice, ii) a reduction ( $\sim 30 \%)$ of water and food intake and iii) a total stool score two-fold higher than after $1 \%$ DSS treatment (21 versus 10 respectively). Moreover, a significant shortening of colonic length (40\%) and absence of digestive contents replaced by severe bleeding were observed in sacrificed mice. Considering the severity of the symptoms, we thought that 5\% DSS was too high to detect any positive effect of the bacterial treatment.

Nevertheless, a significant decrease of total catalase activity was observed in digestive contents of $1 \%$ DSS-treated mice (Figure 3) and this led us to adopt the 1\% DSS model for further experiments to test the antioxidative potential of our strains. 


\begin{tabular}{|c|c|c|c|}
\hline \multicolumn{2}{|l|}{ Phase 1} & \multicolumn{2}{|c|}{ Phase 2} \\
\hline D-8 & D-1 & \multicolumn{2}{|c|}{ D0 to D9 (10 days) } \\
\hline Acclimatization & I.A. & $+1-[$ & each day \\
\hline Group A: $n=10$ & PBS & & PBS 0\% DSS \\
\hline Group B: $n=10$ & PBS & & PBS $1 \%$ DSS \\
\hline Group C: $\quad n=10$ & Lb. casei & Kat- & Lb. casei MnKat- $1 \%$ DSS \\
\hline Group D: $n=10$ & Lb. casei & Kat+ & Lb. casei MnKat+ $1 \%$ DSS \\
\hline Group E: $n=5$ & no admini & ation & $5 \%$ DSS \\
\hline
\end{tabular}

Figure I

Experimental protocol for the induction of moderate colitis. Phases I and 2 correspond to mice acclimatization and to colitis induction (DSS addition in drinking water from J0), respectively. «I.A. » means « intragastric administration 1). Groups of BALB/c mice were used to evaluate the effects of different treatments. Groups used as controls were: i) treated with PBS and either DSS 0\% (no inflammation control) or DSS I\% (inflammation control) or ii) treated with $L b$. casei MnKat - with DSS I\% (control used to dissociate the effects due to the LAB and those due to MnKat). Group E represents a severe colitis control (5\% DSS).

\section{Effects of Lb. casei BL23 producing MnKat on intestinal} inflammation

To evaluate the effects of $L b$. casei BL23 producing or not MnKat catalase on inflammation development, two groups of mice received $5 \times 10^{9} \mathrm{cfu} /$ mouse of either $L b$. casei $\mathrm{MnKat}{ }^{-}$or $L b$. casei $\mathrm{MnKat}^{+}$by intragastric administration one day before starting DSS administration and then daily until sacrifice. Clinical symptoms were compared with DSS-treated mice receiving PBS. As noted above, DSS treatment did not induce body weight or food intake differences compared to untreated mice (group A). $\mathrm{Lb}$. casei BL23 administration did not modify these parameters. Total stool scores were similar for each treated group (10.5; 8.6 and 9.9 for PBS, Lb. casei MnKat ${ }^{-}$and MnKat ${ }^{+}$ groups, respectively) confirming the action of DSS. This parameter showed that either $\mathrm{Lb}$. casei BL23 $\mathrm{MnKat}^{+}$or MnKat- administration failed to prevent totally the development of intestinal inflammation. However, inflammatory scores (macroscopic and histological ones) showed that $L b$. casei BL23 administration limits intestinal mucosal and epithelial damages: i) Total macroscopic scores (Figure 2A) are significantly reduced from $\sim 7$ to $\sim 2$ and $\sim 3$ for PBS and $L b$. casei MnKat or MnKat ${ }^{+}$DSS-treated groups, respectively; and ii) Histological scores were significantly different between DSS-treated and untreated PBS-control groups: The percentage of intact mucosa decreased from $97 \%$ to $88 \%$ in colonic mucosa for DSS untreated and treated groups, respectively (Figure 2B). Administration of $L b$. casei BL23 led in the colon to significant reduction of inflamed epithelial damage. Lb. caseitreated groups are not significantly different from both DSS untreated and treated groups (data not shown). Histological scores of $L b$. casei BL23 DSS-treated groups
A.

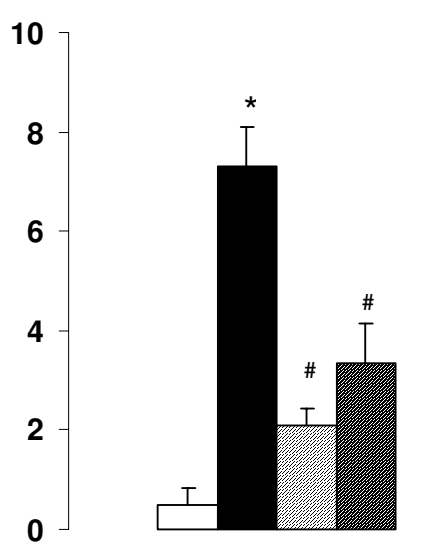

B.

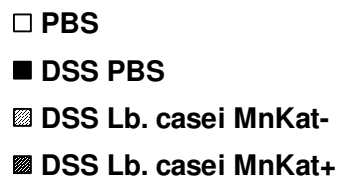

DSS Lb. casei MnKat+

COLON

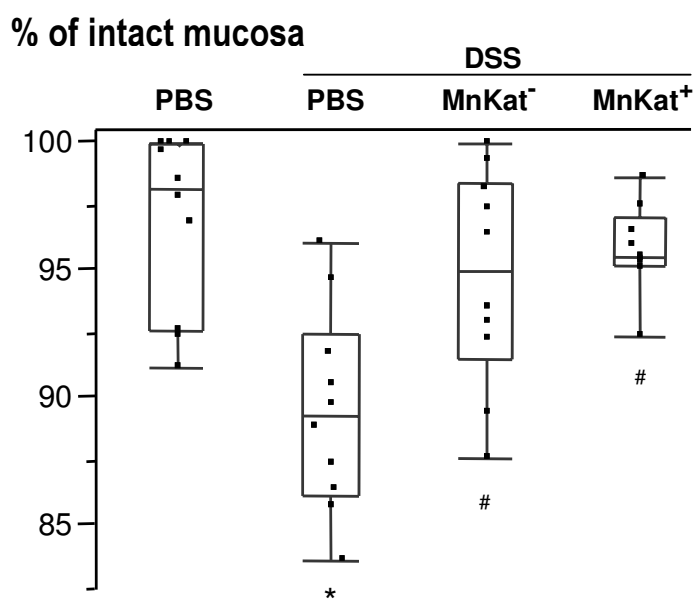

\section{Figure 2}

Effects of $L b$. casei BL23 on the inflammation. A.

Total macroscopic score. Total macroscopic score was the sum of caecal and colonic scores. Data are expressed as mean \pm SEM, $n=10 /$ treatment. (*) $\mathrm{P}<0.05$ versus no inflammation group (PBS) and ${ }^{(\#)}$ versus inflamed control group (PBS DSS). B. Histological score. This parameter is expressed as percentage of intact mucosa and presented using box-andwhisker plots, $n=10 /$ treatment. (*) $\mathrm{P}<0.05$ versus no inflamed group (PBS) and (\#) versus inflamed control group (PBS DSS).

(expressed as percentage of intact mucosa) are not significantly different from DSS-untreated group, in caecum and colon (Figure 2B). No significant difference was observed between $\mathrm{MnKat}^{+}$and MnKat-treated mice for both macroscopic and histological scores. 
Catalase activity $(\mathrm{mU} / \mathrm{mg})$

CAECUM

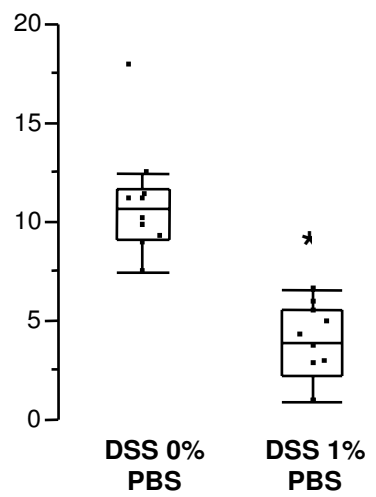

Catalase activity $(\mathrm{mU} / \mathrm{mg})$

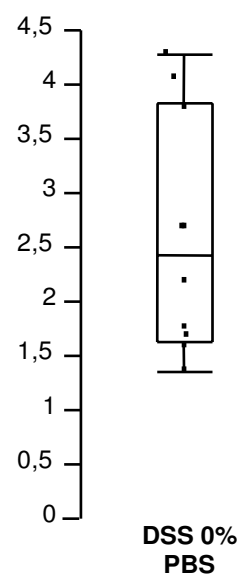

DSS $1 \%$
PBS

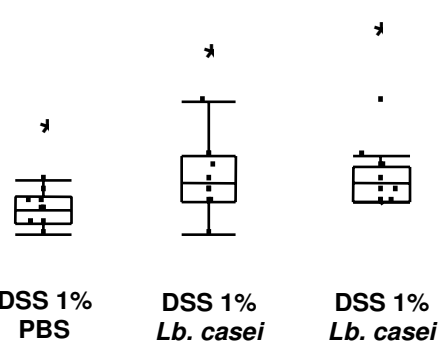

Lb. casei

MnKat $^{+}$

\begin{abstract}
Figure 3
Catalase activity in digestive contents of DSSinduced colitis in mice. Digestive contents homogenates were prepared from MnKat treated mice and from control groups (PBS 0\% DSS, PBS I\% DSS and MnKat- I\% DSS). Total proteins were assayed using Bradford method. Total catalase activity was assessed using colorimetric method and expressed as $\mathrm{mU} / \mathrm{mg}$ of total protein using box-and-whisker plots, $n=10 /$ treatment. $(*) P<0.05$ versus no inflamed group (PBS).
\end{abstract}

We then analysed the effects of both DSS treatment and Lb. casei BL23 administration on mucosal immune cells by ELISA assays. TNF- $\alpha$ and IFN- $\gamma$ pro-inflammatory cytokines, IL-10 anti-inflammatory cytokine and IL-4 Th2-cytokine were quantified in samples of digestive tissues. Contrary to macroscopic and histological scores, no significant difference of cytokines level was observed between DSS-treated and untreated groups and between
Lb. casei BL23 $\mathrm{MnKat}^{+}$or MnKat- treated mice (data not shown).

To estimate the level of oxidative stress induced in our experimental protocol, a quantification of lipid peroxidation in both caecal and colonic tissue homogenates was performed using a malondialdehydes (MDA) assay. MDA concentration was standardised using a commercial MDA solution. The statistical analysis of MDA levels revealed no significant difference between DSS-treated and untreated PBS-control groups (data not shown).

Twenty-four hours after the intragastric administration of $5.10^{9} \mathrm{cfu} /$ mouse, the number of viable cells of $\mathrm{Lb}$. casei BL23 $\mathrm{MnKat}^{+}$or MnKat- in caecal, proximal and distal colonic contents, was determined: The level of $L b$. case BL23 was $\sim 8.10^{5} \mathrm{cfu} / \mathrm{g}$ of digestive contents, in the three tested compartments. The presence of MnKat had no effect on Lb. casei BL23 survival in digestive contents.

The total catalase activity in digestive contents from caecum and colon of DSS-treated and untreated mice and of Lb. casei MnKat and MnKat ${ }^{+}$-treated mice was quantified. A significant decrease was observed for all DSS-treated groups compared to untreated mice for both caecal and colonic homogenates (Figure 3). No significant difference was observed between PBS and Lb. casei $\mathrm{MnKat}^{+}$or MnKat ${ }^{-}$ . The production of MnKat by $L b$. casei BL 23 did not restore the initial level of catalase activity in digestive contents (Figure 3).

In summary, our results showed that the intragastric administration of $\mathrm{Lb}$. casei BL23 limits but does not impair the development of mucosal and epithelial inflammation damage in both caecum and colon of DSS-treated mice. This suggests that i) $1 \%$ DSS model leads to a significant decrease of catalase activity in digestive contents; ii) Lb. casei BL23 exerts natural anti-inflammatory effects by still unknown mechanisms and that iii) the delivery of MnKat catalase has no effect on the development of inflammation in the tested conditions.

\section{Discussion and conclusion}

The aim of this study was to determine the impact of the in situ delivery of catalase-producing lactobacilli in the DT on the development of inflammation and oxidative intestinal damage in mice. Our strategy, based on the intragastric administration of both isogenic strains of $L b$. casei BL23 producing or not MnKat, allowed us to distinguish the respective effects of the strain and of the catalase activity. Both $\mathrm{Lb}$. casei BL23 treatments led to anti-inflammatory effects for DSS-treated mice, suggesting that the BL23 strain itself is responsible for the protective effect. The mechanisms and bacterial components involved in these anti-inflammatory effects remain unknown. 
In the tested conditions, no protection due to the catalase was observed. Two hypotheses could explain this result: i) no induction of effective oxidative stress in our moderate colitis model and/or ii) a too low catalase activity delivered in digestive tractus via $L b$. casei BL23 $\mathrm{MnKat}^{+}$. No increase of intestinal oxidative stress in our model was detected using a first method (evaluation of MDA level in digestive tissues homogenates).

Using a colorimetric method, we observed for the first time a significant decrease of the total catalase activity in the intestinal lumen of all DSS-treated mice. The four-fold higher catalase activity of caecal contents compared to colonic contents is coherent with the decrease of aerobiosis from the stomach to the rectum. DSS-induced modifications of the homeostasis of the intestinal microbiota could explain this reduction of catalase activity. Dominant colon species are strict anaerobic bacteria like Bacteroides, Bifidobacterium, Clostridium coccoides and Cl. leptum whereas other groups like Enterobacteriaceae or Lactobacillus are subdominant. Among microbiota, some bacteria possess catalase activity as described for Bacteroides fragilis [35]. A loss of diversity of Bacteroides and Enterobacteriaceae groups was observed in biopsies of patients with Crohn's disease or ulcerative colitis [4]. In our experiments, the reason of the observed decrease is difficult to determine because the composition of the microbiota of the conventional mice used is unknown. Previous studies showed that activities of antioxidative enzymes produced by epithelial cells were modified in biopsies of patients with Crohn's disease or ulcerative colitis $[12,15,16]$. In this study, we showed for the first time a reduction of antioxidative defences of caecal and colonic contents during the induction of inflammation. All these data suggest a global deficiency of antioxidative enzymes during intestinal inflammation that might be involved in the mechanism of development of the disease.

The second reason of the absence of any incidence of MnKat production could be a too low catalase activity and more generally, a too low antioxidative potential. Our results showed that the administration of our MnKat-producing strain did not restore the initial catalase activity level in the digestive contents. Increasing catalase activity seems to be necessary. To optimise our antioxidative strategy, evaluation of the effects of co-administration of $L b$. casei BL23 strains producing high levels of MnKat and SOD from L. lactis [36] as some previous studies showed the positive impact of increased SOD activity in intestinal inflammation models will be relevant $[20,21,37,38]$.

In our test conditions, no increase of mucosal pro-inflammatory cytokines (TNF- $\alpha$ and IFN- $\gamma$ ) or decrease of IL-4 and IL-10 was observed in DSS-treated mice. The administration of both $\mathrm{Lb}$. casei BL23 strains did not induce modification of mucosal cytokines. In contrast, an increase of TNF- $\alpha$ in DSS-induced colitis was previously observed either at the gene expression level $[39,40]$ or at the systemic protein level $[22,41]$. In the DSS-colitis model, the modification of mucosal cytokine levels could occur with the apparition of chronic inflammation depending of the mice used: Melgar et al. (2005) observed an increase of IL-1 $\beta$, IL-12 and IFN- $\gamma$ levels between 100and 1000-fold in $\mathrm{C} 57 \mathrm{Bl} / 6$ mice (where the colitis progresses in chronicity) in contrast to $\mathrm{BALB} / \mathrm{c}$ mice where cytokines levels did not increase [42]. These data could explain the absence of the modulation of cytokine levels in our experiments performed with BALB/c mice. For now, the pathways responsible for inflammation development in the DSS-colitis model are not clearly understood. No modulation of mucosal cytokines by $L b$. casei BL23 administration in vivo was observed. So far, such modulations were only observed in in vitro co-cultures between $\mathrm{LAB}$ and peripheral blood mononuclear cells $[27,30]$. No published data correlate cytokine modulations by LAB in in vitro and in vivo assays.

In conclusion, our results showed anti-inflammatory capacities of $\mathrm{Lb}$. casei BL23 strain in a DSS-induced colitis model. This original result is in accordance with a recent one observed in TNBS-induced colitis [43] and previous ones obtained with other $L b$. casei strains. Both Shirota and DN-114001 strains impair inflammation development in a DSS-induced $[29,30]$ and TNBS-induced [44] colitis model, respectively. These two colitis models mimic Crohn's disease (for TNBS) and ulcerative colitis (for DSS) and the efficiency of these Lb. casei strains in both open interesting potential uses of them. Several studies based on host-probiotic interactions aimed to identify the still unkown mechanisms responsible for these antiinflammatory effects: Borruel et al. first observed that $L b$. casei and $L b$. bulgaricus are able to interact with immune cells and to modulate pro-inflammatory cytokines using co-cultures of LAB with biopsies of patients with active Crohn's disease, but the mechanism of action is still not known [45]. Two recent studies established a link between probiotic anti-inflammatory capacities and Toll-like receptors (TLR) pathway $[27,46]$. Although the involvement of TLR in the stimulation of the immune system by the bacterial components is well documented, their implication in inflammatory diseases remains confusing: they were also shown to be essential to maintain a mucosal homeostasis during intestinal inflammation, as observed with MyD88\% knockout mice which are very sensible to the induction of DSS colitis [5].

The increasing availability of probiotic genomic sequences constitutes a major progress to understand molecular mechanisms involved in the anti-inflammatory capacities observed. This will be facilitated by the use in 
parallel of cellular and animals models and could result in a global view of probiotic-host interactions.

\section{Methods}

\section{Animals and treatments}

Conventional male BALB/c mice (Janvier, Le Genest Saint Isle, France), 7 wk of age, were reared by groups of 5 mice per cage in Texler-type isolators (La Calhène, Vélizy, France) to limit GMO dissemination, and maintained in an environmentally controlled room $\left(21^{\circ} \mathrm{C}\right)$ with a 12 -h light-dark cycle as described [47]. Food (UAR, Villemoisson, France) and water were consumed ad libitum; food intake and body weight were recorded every day. All experiments were carried out in accordance with the institutional guidelines.

\section{Bacterial strains and growth conditions}

Cultures of both strains of $L b$. casei BL23 containing either the control plasmid pLEM415 ( "MnKat"») or catalase-carrier plasmid pLEM415mnkat ( MnKat ${ }^{+} »$ ) were performed in MRS medium (Difco) containing erythromycin (Em; 5 $\mu \mathrm{g} / \mathrm{mL}$ ) and incubated $24 \mathrm{~h}$ at $37^{\circ} \mathrm{C}$. The bacterial suspension used for the treatment of mice was prepared as follows: $50 \mathrm{~mL}$ of stationary phase cultures were centrifuged $(6000 \mathrm{~g}, 10 \mathrm{~min})$, and the collected cells were washed and resuspended in phosphate buffered saline (PBS; $\mathrm{NaCl} 8 \mathrm{~g} /$ $\mathrm{L}, \mathrm{KCl} 0.2 \mathrm{~g} / \mathrm{L}, \mathrm{NaH}_{2} \mathrm{PO}_{4} 1.44 \mathrm{~g} / \mathrm{L}, \mathrm{K}_{2} \mathrm{HPO}_{4} 0.24 \mathrm{~g} / \mathrm{L} \mathrm{pH}$ 7.4) to obtain a final concentration of $2.5 .10^{10} \mathrm{cfu} / \mathrm{mL}$ (25-fold concentrated cultures). Bacterial population level of cell suspensions was checked by cfu counting, and catalase activity was verified as previously described [34]. Briefly, $10 \mu \mathrm{L}$ of $\mathrm{H}_{2} \mathrm{O}_{2}(8 \mathrm{M})$ was added to $30 \mu \mathrm{L}$ of bacterial suspension and $\mathrm{O}_{2}$ gas bubbles coming from $\mathrm{H}_{2} \mathrm{O}_{2}$ degradation were observed. Each mouse received $0.2 \mathrm{~mL}$ of bacterial suspension by intragastric administration $\left(5.10^{9} \mathrm{cfu} /\right.$ mouse/day). For enumeration of $L b$. case $i$ in the DT, digestive contents were dissolved in cold peptone (1 $\mathrm{g} / \mathrm{L}$; dilution $1 / 10=1 \mathrm{~mL}$ for $0.1 \mathrm{~g}$ of digestive contents) and adequate dilutions were plated on MRS containing $\operatorname{Em}(5 \mu \mathrm{g} / \mathrm{mL})$ and nalidixic acid $(40 \mu \mathrm{g} / \mathrm{mL})$, an inhibitor of Gram negative bacteria, using a SpiralPlater ${ }^{\circledR}$ (Interscience, France) and incubated $48 \mathrm{~h}$ at $37^{\circ} \mathrm{C}$ before counting.

\section{Induction of colitis}

The experimental protocol is presented in Figure 1. The main experiment was performed with 4 groups of mice (n $=10)$. After acclimatization, colonic inflammation was induced by the addition of $1 \%(\mathrm{w} / \mathrm{v})$ DSS (40 kDa; ICN $\mathrm{n}^{\circ} 160110$ ) in drinking water for 10 days (group B/C/D; $\mathrm{DSS}^{+}$) until their sacrifice for digestive tissue collection. The no-inflammation control group received no DSS (group A; DSS-). An additional group $(\mathrm{E} ; \mathrm{n}=5)$, was used as severe colitis control and received 5\% DSS. Intragastric administration of bacteria was performed the day before the beginning of DSS treatment and each following day until sacrifice: groups A and B received PBS, group C $L b$. casei MnKat' and group D Lb. casei MnKat ${ }^{+}$.

\section{Collection of digestive tissues and contents}

After the 10 days of DSS treatment, the animals were killed by cervical dislocation. Three segments of the digestive tract (caecum, proximal colon and distal colon) were then removed; caecal and colonic contents were aseptically collected and immediately used for $L b$. casei enumeration (group $\mathrm{C}$ and $\mathrm{D} ; \mathrm{n}=10$ ) or for total catalase activity assessment $(\mathrm{n}=10)$. Caecal, proximal and distal colonic mucosa were cut longitudinally and cleaned with sterile PBS. After evaluation of macroscopic damage and for each DT segment, i) for histological examination, mucosa was rolled up on itself over the full length to obtain a "swiss roll" (Figure 4B) and immediately fixed in 4\% formaldehyde PBS pH 7.4, dehydrated, and paraffin embedded for histological observations $(\mathrm{n}=10)$ or ii) for MDA assay, mucosa was immediately placed in Tris-HCl buffer $(0.1$ $\mathrm{M}$, pH 7.5, Tween $800.1 \%$; $60 \mathrm{mg}$ of digestive tissues/ $\mathrm{mL}$ ) before homogenisation and iii) for cytokines assays, a digestive tissue segment $(0.5 \mathrm{~cm})$ was placed in $500 \mu \mathrm{L}$ of cold antiprotease buffer (Protease Inhibitor Cocktail Tablets, Roche ${ }^{\circledast}$ ) before homogenisation using a BeatBeater $^{\mathrm{TM}}$ (BioSpec Products). A second lot (four groups of 10 mice) which received the same experimental design was used to assay lipid peroxidation (see the corresponding paragraph).

\section{Assessment of colonic damage and inflammation \\ Body weight and stool score}

Clinical symptoms were assessed every day during the course of the experiment. Body weight gain and stool scores were calculated until sacrifice following the protocol of Gaudier et al [39] with slight modifications: A stool score (Figure 4A) was calculated each day taking account of consistency and bleeding. The presence of digestive contents and faecal blood was assessed visually and with HémocultII $^{\circledast}$ detection test (SKD, France). Total stool score was the sum of daily scores (from D0 to D9) for each mouse.

\section{Macroscopic and histological scoring of mucosa inflammation}

Macroscopic damage of caecal and colonic mucosa was scored visually using a scale taking into account three parameters (mucosa thickening, ulceration and bleeding in contents) as described previously by Gaudier et al [39] (Figure 4A). Caecal and colonic macroscopic scores were obtained by addition of these three partial scores. Total macroscopic scores were the sum of caecal and colonic scores. For histological observations, sections $(5 \mu \mathrm{m})$ of paraffin embedded tissues were stained with haematoxylin and eosin, and observed by microscopy for inflammation scoring. Histological crypt scoring for inflammation 
A.

\begin{tabular}{ccccc}
\hline \multirow{2}{*}{ Score } & \multirow{2}{*}{ Stool score } & \multicolumn{3}{c}{ Macroscopic score } \\
\cline { 3 - 5 } & & Mucosal thickening & Ulcerative sites & Bleeding digestive contents \\
\hline \hline $\mathbf{0}$ & normal & normal & no site & No \\
$\mathbf{1}$ & soft formed & moderate & focal hyperaemia & moderate \\
$\mathbf{2}$ & bleeding* & severe & ulcerations (1-3 sites) & severe \\
$\mathbf{3}$ & & & ulcerations $(>3$ sites $)$ & \\
\hline
\end{tabular}

B.

\begin{tabular}{cc}
\hline Grade & Histological score \\
\hline \hline $\mathbf{0}$ & Intact crypt \\
$\mathbf{1}$ & Immune cells infiltration and loss of the basal part of the crypt \\
$\mathbf{2}$ & Immune cells infiltration with loss of entire crypt but intact surface epithelium \\
\hline
\end{tabular}
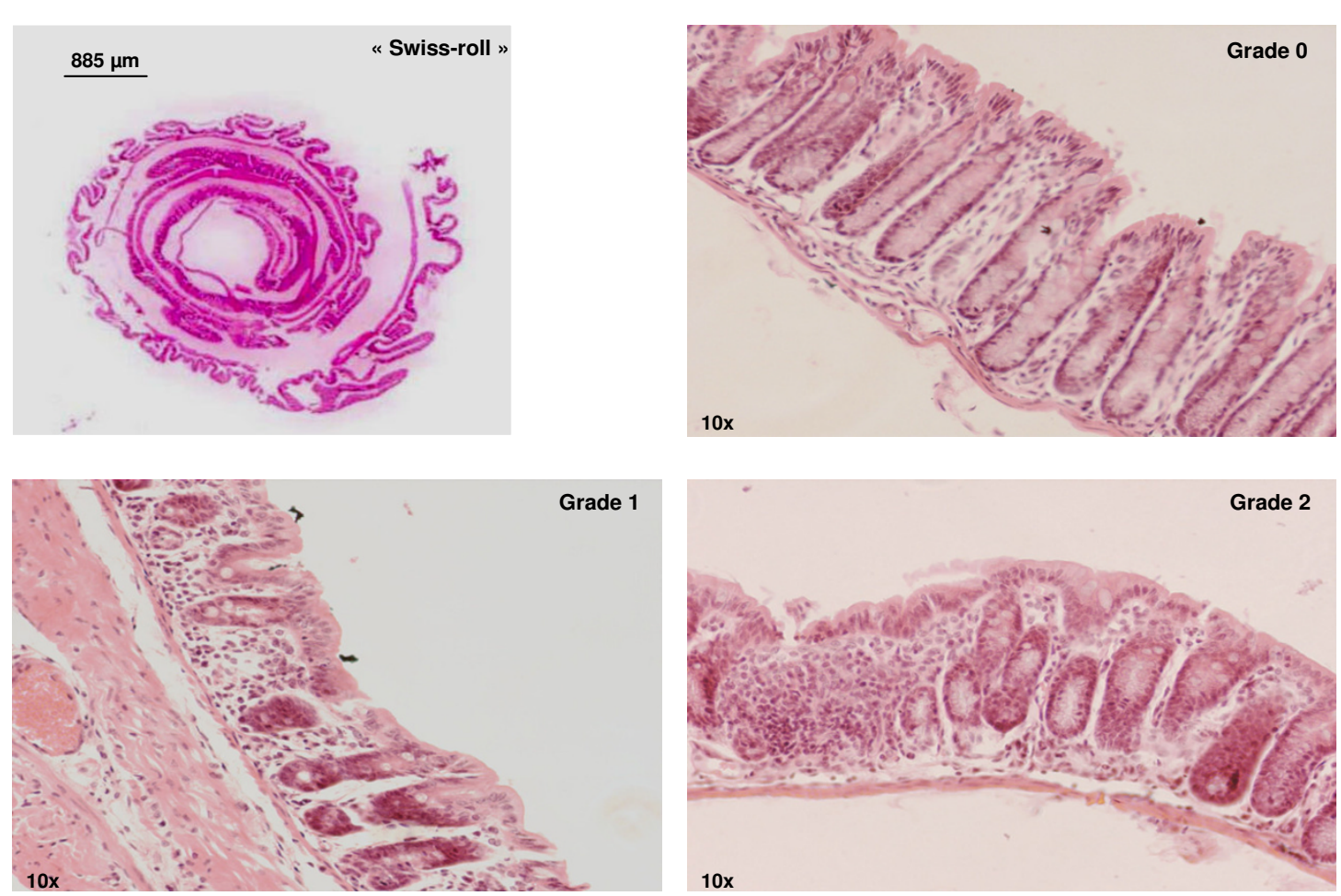

Figure 4

Inflammation scores determination. A. Stool and macroscopic scores. Stool scores were determined during the phase of colitis induction, taking into account stool consistency and bleeding. The three macroscopic parameters (mucosal thickening, ulcerative sites and bleeding inside digestive contents) were added together to obtain macroscopic scores for caecum, proxi$\mathrm{mal}$ and distal colon. Separate scores were added up to obtain a total macroscopic score for each mouse. (*: presence of blood using Hémocult|l ${ }^{\circledR}$ detection test). B. Histological score. Swiss rolls were used to calculate a percentage of intact mucosa for each digestive segment. Three grades were defined depending on the mucosal state. The percentage of mucosal length in grade 0, I or 2 was calculated by microscopic observation of hematoxylin/eosin-stained sections $(5 \mu \mathrm{m})$ and using LuciaG ${ }^{\circledR}$ software to measure the length of each section. Results were expressed as percentage of intact mucosa. 
was performed blindly and took into account the extent of immune cells infiltration, integrity of the crypts and of surface epithelium (Figure 4B). The proportion of mucosa length area involved for each grade ( 0 to 2 ) was quantified by image analysis with LuciaG $^{\circledast}$ software (Laboratory Imaging Ltd, Praha, Czech Republic). Percentage of intact mucosa area $[\Sigma($ area in grade 0$) / \Sigma($ area in grade 0,1 and $2) \times 100$ ] was calculated for each DT segment.

\section{Cytokine assays}

Digestive tissues of caecum, proximal and distal colon were mechanically homogenized in cold antiprotease buffer using a BeatBeater ${ }^{\mathrm{TM}}$ (BioSpec Products) and after centrifugation for $30 \mathrm{~min}$ at $16000 \mathrm{~g}$ and $4{ }^{\circ} \mathrm{C}$, the supernatant was stocked at $-20^{\circ} \mathrm{C}$. Total proteins were quantified in digestive homogenates by a Bradford assay. A mix of the three homogenates (caecum, proximal and distal colon) in equal proportion of total proteins was prepared for each mouse and used for the assay of cytokines (TNF $\alpha$, IFN $\gamma$, IL-10 and IL-4) using ELISA kits (Ebioscience ${ }^{\circledR}$ ). Cytokine levels are expressed in $\mathrm{ng} / \mathrm{mg}$ of total proteins.

\section{Lipid peroxidation}

An estimation of the level of lipid peroxidation in digestive tissues was obtained using the method described by Gérard-Monnier et al [48] which is based on the colorimetric assay of malondialdehydes (MDA, derived product of peroxidized lipids). Digestive tissue homogenates (divided in two parts: caecum and colon) were obtained by mechanic disruption using a BeatBeater ${ }^{\mathrm{TM}}$ (BioSpec Products). After centrifugation at $16000 \mathrm{~g}$ for $15 \mathrm{~min}$, $4{ }^{\circ} \mathrm{C}$, supernatants were stocked at $-80^{\circ} \mathrm{C}$. For the assay, 75 $\mu \mathrm{L}$ of homogenate were acidified by the addition of $75 \mu \mathrm{L}$ of sodium acetate buffer $(0.4 \mathrm{M})$ containing $5 \%$ concentrated $\mathrm{HCl}(\mathrm{pH} \sim 1.2)$ and hydrolyzed for $80 \mathrm{~min}$ at $60^{\circ} \mathrm{C}$. After cooling, $700 \mu \mathrm{L}$ of 1-methyl-2-phenylindole (14.3 $\mathrm{mM}$; dissolved in acetonitrile/methanol 3:1) and $150 \mu \mathrm{L}$ of concentrated $\mathrm{HCl}$ were added. The mixture was incubated at $45^{\circ} \mathrm{C}$ for $80 \mathrm{~min}$. Produced MDA forms a stable chromophore which absorbs light at $586 \mathrm{~nm}$ (absorbance measured using a spectrophotometer after centrifugation at $8000 \mathrm{~g} 10 \mathrm{~min}$ ). Non-specific coloration was measured using homogenate buffer instead of tissue homogenate. The reaction was standardised with commercial hydrolysed MDA (Merck, Darmstadt, Germany) and the results expressed in nmol of MDA/g of tissue.

\section{Catalase activity assay in digestive contents}

The assay was performed using the Amplex-Red ${ }^{\circledR}$ kit (Invitrogen). Caecal and colonic contents were collected and suspended in $500 \mu \mathrm{L}$ of cold reaction buffer supplemented with antiprotease (Protease Inhibitor Cocktail Tablets, Roche ${ }^{\varpi}$. Homogenates were obtained by mechanical disruption for $40 \mathrm{~s}$ at speed 6.5 using a Fast Prep FP120 (ThermoSavant). After centrifugation (15 $\min , 16000 \mathrm{~g}, 4^{\circ} \mathrm{C}$ ), supernatants were aliquoted and stocked at $-80^{\circ} \mathrm{C}$. Total proteins were quantified in the extracts using the Bradford method. Calorimetrically assayed, catalase activity was standardised using a commercial catalase solution and expressed in $\mathrm{mU} / \mathrm{mg}$ of total protein.

\section{Statistical analysis}

All data are expressed as mean \pm SEM. The effects of DSS treatment and $L b$. case $i$ administration were assessed by an ANOVA test using JUMP5. ${ }^{\circledast}$ software. Differences with P $<0.05$ were considered significant.

\section{Authors' contributions}

TR, JJG, LGBH, CH and CF carried out the molecular genetic studies and participated in experiments. TR and PL drafted the manuscript. LGBH carried out the immunoassays. $\mathrm{CH}$ and GC participated in the design of the study. TR and LGBH performed the statistical analysis. All authors read and approved the final manuscript.

\section{Acknowledgements}

$T$. Rochat was recipient of a grant from the Ministère de l'Education Nationale, de la Recherche et de la Technologie (MENRT, France). This work was supported in part by the Scientific Mission of Syndifrais. We are grateful to Martine Bensaada, Martine Rival and Estelle Gaudier for technical assistance. We thank Maarten van de Guchte and Naima Cortes-Perez for their precious help in the preparation of this manuscript and statistical analyses, respectively.

\section{References}

I. Darfeuille-Michaud A, Boudeau J, Bulois P, Neut C, Glasser AL, Barnich N, Bringer MA, Swidsinski A, Beaugerie L, Colombel JF: High prevalence of adherent-invasive Escherichia coli associated with ileal mucosa in Crohn's disease. Gastroenterology 2004, I 27(2):4|2-42|.

2. Glasser AL, Boudeau J, Barnich N, Perruchot MH, Colombel JF, Darfeuille-Michaud A: Adherent invasive Escherichia coli strains from patients with Crohn's disease survive and replicate within macrophages without inducing host cell death. Infect Immun 200I, 69(9):5529-5537.

3. Manichanh C, Rigottier-Gois L, Bonnaud E, Gloux K, Pelletier E, Frangeul L, Nalin R, Jarrin C, Chardon P, Marteau P, Roca J, Dore J: Reduced diversity of faecal microbiota in Crohn's disease revealed by a metagenomic approach. Gut 2006, 55(2):205-2II.

4. Ott SJ, Musfeldt M, Wenderoth DF, Hampe J, Brant O, Folsch UR, Timmis KN, Schreiber S: Reduction in diversity of the colonic mucosa associated bacterial microflora in patients with active inflammatory bowel disease. Gut 2004, 53(5):685-693.

5. Rakoff-Nahoum S, Paglino J, Eslami-Varzaneh F, Edberg S, Medzhitov $\mathrm{R}$ : Recognition of commensal microflora by toll-like receptors is required for intestinal homeostasis. Cell 2004, I | 8(2):229-24I.

6. Seksik P, Rigottier-Gois L, Gramet G, Sutren M, Pochart P, Marteau $P$, Jian R, Dore J: Alterations of the dominant faecal bacterial groups in patients with Crohn's disease of the colon. Gut 2003, 52(2):237-242.

7. Swidsinski A, Weber J, Loening-Baucke V, Hale LP, Lochs H: Spatial organization and composition of the mucosal flora in patients with inflammatory bowel disease. J Clin Microbiol 2005, 43(7):3380-3389.

8. Roos D: The involvement of oxygen radicals in microbicidal mechanisms of leukocytes and macrophages. Klin Wochenschr |991, 69(2 I-23):975-980. 
9. Marletta MA, Spiering MM: Trace elements and nitric oxide function. J Nutr 2003, 133(5 Suppl I): 143IS-3S.

10. Arnhold J: Properties, functions, and secretion of human myeloperoxidase. Biochemistry (Mosc) 2004, 69(I):4-9.

II. Keshavarzian A, Banan A, Farhadi A, Komanduri S, Mutlu E, Zhang Y, Fields JZ: Increases in free radicals and cytoskeletal protein oxidation and nitration in the colon of patients with inflammatory bowel disease. Gut 2003, 52(5):720-728.

12. Lih-Brody L, Powell SR, Collier KP, Reddy GM, Cerchia R, Kahn E, Weissman GS, Katz S, Floyd RA, McKinley MJ, Fisher SE, Mullin GE: Increased oxidative stress and decreased antioxidant defenses in mucosa of inflammatory bowel disease. Dig Dis Sci I 996, 4 I (10):2078-2086.

13. Sedghi S, Fields JZ, Klamut M, Urban G, Durkin M, Winship D, Fretland $D$, Olyaee $M$, Keshavarzian A: Increased production of luminol enhanced chemiluminescence by the inflamed colonic mucosa in patients with ulcerative colitis. Gut 1993, 34(9): II9I-II 97.

14. Simmonds NJ, Allen RE, Stevens TR, Van Someren RN, Blake DR, Rampton DS: Chemiluminescence assay of mucosal reactive oxygen metabolites in inflammatory bowel disease. Gastroenterology 1992, 103(I): I86-196.

15. Kruidenier L, Kuiper I, van Duijn W, Marklund SL, van Hogezand RA, Lamers CB, Verspaget HW: Differential mucosal expression of three superoxide dismutase isoforms in inflammatory bowel disease. J Pathol 2003, 20 I (I):7-I6.

16. Tuzun A, Erdil A, Inal V, Aydin A, Bagci S, Yesilova Z, Sayal A, Karaeren N, Dagalp K: Oxidative stress and antioxidant capacity in patients with inflammatory bowel disease. Clin Biochem 2002, 35(7):569-572.

17. Chiarpotto E, Scavazza A, Leonarduzzi G, Camandola S, Biasi F, Teggia PM, Garavoglia M, Robecchi A, Roncari A, Poli G: Oxidative damage and transforming growth factor beta $I$ expression in pretumoral and tumoral lesions of human intestine. Free Radic Biol Med 1997, 22(5):889-894.

18. McKenzie SJ, Baker MS, Buffinton GD, Doe WF: Evidence of oxidant-induced injury to epithelial cells during inflammatory bowel disease. J Clin Invest 1996, 98(I):|36-14|.

19. Araki $Y$, Andoh A, Fujiyama $Y$ : The free radical scavenger edaravone suppresses experimental dextran sulfate sodiuminduced colitis in rats. Int J Mol Med 2003, I 2(1): 125-129.

20. Kruidenier L, van Meeteren ME, Kuiper I, Jaarsma D, Lamers CB, Zijlstra FJ, Verspaget HW: Attenuated mild colonic inflammation and improved survival from severe DSS-colitis of transgenic Cu/Zn-SOD mice. Free Radic Biol Med 2003, 34(6):753-765.

21. Ogawa Y, Kanatsu K, lino T, Kato S, Jeong YI, Shibata N, Takada K, Takeuchi K: Protection against dextran sulfate sodiuminduced colitis by microspheres of ellagic acid in rats. Life Sci 2002, 7 I(7):827-839.

22. Oz HS, Chen TS, McClain CJ, de Villiers WJ: Antioxidants as novel therapy in a murine model of colitis. J Nutr Biochem 2005, 16(5):297-304.

23. Pelissier MA, Muller C, Hill M, Morfin R: Protection against dextran sodium sulfate-induced colitis by dehydroepiandrosterone and 7alpha-hydroxy-dehydroepiandrosterone in the rat. Steroids 2006, 7 I(3):240-248.

24. Gionchetti P, Amadini C, Rizzello F, Venturi A, Poggioli G, Campieri M: Probiotics for the treatment of postoperative complications following intestinal surgery. Best Pract Res Clin Gastroenterol 2003, I7(5):82I-83I.

25. Mimura T, Rizzello F, Helwig U, Poggioli G, Schreiber S, Talbot IC, Nicholls RJ, Gionchetti P, Campieri M, Kamm MA: Once daily high dose probiotic therapy (VSL\#3) for maintaining remission in recurrent or refractory pouchitis. Gut 2004, 53(I): I08-I I4.

26. Peran L, Camuesco D, Comalada M, Nieto A, Concha A, Diaz-Ropero MP, Olivares M, Xaus J, Zarzuelo A, Galvez J: Preventative effects of a probiotic, Lactobacillus salivarius ssp. salivarius, in the TNBS model of rat colitis. World J Gastroenterol 2005, I I (33):5185-5192.

27. Grangette $C$, Nutten $S$, Palumbo E, Morath S, Hermann C, Dewulf J, Pot B, Hartung T, Hols P, Mercenier A: Enhanced antiinflammatory capacity of a Lactobacillus plantarum mutant synthesizing modified teichoic acids. Proc Natl Acad Sci U S A 2005, 102(29): 10321-10326.

28. Osman N, Adawi D, Ahrne S, Jeppsson B, Molin G: Modulation of the effect of dextran sulfate sodium-induced acute colitis by the administration of different probiotic strains of Lactobacillus and Bifidobacterium. Dig Dis Sci 2004, 49(2):320-327.

29. Herias MV, Koninkx JF, Vos JG, Huis in't Veld JH, van Dijk JE: Probiotic effects of Lactobacillus casei on DSS-induced ulcerative colitis in mice. Int J Food Microbiol 2005, I03(2): I43-I55.

30. Matsumoto S, Hara T, Hori T, Mitsuyama K, Nagaoka M, Tomiyasu N, Suzuki A, Sata M: Probiotic Lactobacillus-induced improvement in murine chronic inflammatory bowel disease is associated with the down-regulation of pro-inflammatory cytokines in lamina propria mononuclear cells. Clin Exp Immunol 2005, I 40(3):417-426.

31. Steidler L, Hans W, Schotte L, Neirynck S, Obermeier F, Falk W, Fiers $W$, Remaut $E$ : Treatment of murine colitis by Lactococcus lactis secreting interleukin- 10 . Science 2000, 289(5483): I $352-1355$.

32. Igarashi T, Kono Y, Tanaka K: Molecular cloning of manganese catalase from Lactobacillus plantarum. J Biol Chem 1996, 27 I (47):2952I-29524.

33. Rochat T, Miyoshi A, Gratadoux JJ, Duwat P, Sourice S, Azevedo V, Langella P: High-level resistance to oxidative stress in Lactococcus lactis conferred by Bacillus subtilis catalase KatE. Microbiology 2005, I5 I (Pt 9):30 I I-30 I8.

34. Rochat T, Gratadoux J], Gruss A, Corthier G, Maguin E, Langella P, van de Guchte M: Production of a heterologous nonheme catalase by Lactobacillus casei: an efficient tool for removal of $\mathrm{H} 2 \mathrm{O} 2$ and protection of Lactobacillus bulgaricus from oxidative stress in milk. Appl Environ Microbiol 2006, 72(8):5I43-5।49.

35. Rocha ER, Smith CJ: Biochemical and genetic analyses of a catalase from the anaerobic bacterium Bacteroides fragilis. Bacteriol 1995, I77(I I):3 III-3 II9.

36. Sanders JW, Leenhouts KJ, Haandrikman AJ, Venema G, Kok J: Stress response in Lactococcus lactis: cloning, expression analysis, and mutation of the lactococcal superoxide dismutase gene. J Bacteriol 1995, I77( 1 8):5254-5260.

37. Segui J, Gironella M, Sans M, Granell S, Gil F, Gimeno M, Coronel P, Pique JM, Panes J: Superoxide dismutase ameliorates TNBSinduced colitis by reducing oxidative stress, adhesion molecule expression, and leukocyte recruitment into the inflamed intestine. J Leukoc Biol 2004, 76(3):537-544.

38. Han W, Mercenier A, Ait-Belgnaoui A, Pavan S, Lamine F, van S II, Kleerebezem M, Salvador-Cartier C, Hisbergues M, Bueno L, Theodorou V, Fioramonti J: Improvement of an experimental colitis in rats by lactic acid bacteria producing superoxide dismutase. Inflamm Bowel Dis 2006, I 2(I I): I044-I052.

39. Gaudier E, Michel C, Segain JP, Cherbut C, Hoebler C: The VSL\# 3 Probiotic Mixture Modifies Microflora but Does Not Heal Chronic Dextran-Sodium Sulfate-Induced Colitis or Reinforce the Mucus Barrier in Mice. J Nutr 2005, I35(I 2):2753-276I.

40. Herfarth H, Brand K, Rath HC, Rogler G, Scholmerich J, Falk W: Nuclear factor-kappa B activity and intestinal inflammation in dextran sulphate sodium (DSS)-induced colitis in mice is suppressed by gliotoxin. Clin Exp Immunol 2000, I 20(I):59-65.

4I. Murphy MP, Packer MA, Scarlett JL, Martin SW: Peroxynitrite: a biologically significant oxidant. Gen Pharmacol 1998 3I(2): I79-186.

42. Melgar S, Karlsson A, Michaelsson E: Acute colitis induced by dextran sulfate sodium progresses to chronicity in C57BL/6 but not in BALB/c mice: correlation between symptoms and inflammation. Am 」 Physiol Gastrointest Liver Physiol 2005, 288(6): $G \mid 328-38$.

43. Foligne B, Nutten S, Grangette C, Dennin V, Goudercourt D, Poiret S, Dewulf J, Brassart D, Mercenier A, Pot B: Correlation between in vitro and in vivo immunomodulatory properties of lactic acid bacteria. World I Gastroenterol 2007, I3(2):236-243.

44. Llopis M, Antolin M, Guarner F, Salas A, Malagelada JR: Mucosal colonisation with Lactobacillus casei mitigates barrier injury induced by exposure to trinitronbenzene sulphonic acid. Gut 2005, 54(7):955-959.

45. Borruel N, Carol M, Casellas F, Antolin M, de Lara F, Espin E, Naval J, Guarner F, Malagelada JR: Increased mucosal tumour necrosis factor alpha production in Crohn's disease can be downregulated ex vivo by probiotic bacteria. Gut 2002, 5 I (5):659-664.

46. Rachmilewitz D, Katakura K, Karmeli F, Hayashi T, Reinus C, Rudensky B, Akira S, Takeda K, Lee J, Takabayashi K, Raz E: Toll-like receptor 9 signaling mediates the anti-inflammatory effects 
of probiotics in murine experimental colitis. Gastroenterology 2004, I 26(2):520-528.

47. Oozeer R, Goupil-Feuillerat N, Alpert CA, van de Guchte M, Anba J, Mengaud J, Corthier G: Lactobacillus casei is able to survive and initiate protein synthesis during its transit in the digestive tract of human flora-associated mice. Appl Environ Microbiol 2002, 68(7):3570-3574.

48. Gerard-Monnier D, Erdelmeier I, Regnard K, Moze-Henry N, Yadan JC, Chaudiere J: Reactions of I-methyl-2-phenylindole with malondialdehyde and 4-hydroxyalkenals. Analytical applications to a colorimetric assay of lipid peroxidation. Chem Res Toxicol 1998, I I(10): I 176-II83.

Publish with Bio Med Central and every scientist can read your work free of charge

"BioMed Central will be the most significant development for disseminating the results of biomedical research in our lifetime. "

Sir Paul Nurse, Cancer Research UK

Your research papers will be:

- available free of charge to the entire biomedical community

- peer reviewed and published immediately upon acceptance

- cited in PubMed and archived on PubMed Central

- yours - you keep the copyright

Submit your manuscript here:

http://www.biomedcentral.com/info/publishing_adv.asp
BioMedcentral 